\section{Ian T. Jackson}

Surajit Bhattacharya ${ }^{1}$

${ }^{1}$ Department of Plastic, Reconstructive and Aesthetic Surgery, Sahara Hospital, Lucknow, Uttar Pradesh, India

Indian J Plast Surg:2020;53:315-316

It is surely the end of an era. Mr. Ian T. Jackson is no more with us and we, the Plastic Surgery fraternity in India, and indeed the world over, mourn his demise. With his ever-smiling face and Scottish accent, he charmed the patients and trainees alike. Today, we pray to God to let his soul rest in eternal peace and mourn his demise with his wife and our friend Marjorie and their children.

Mr. Jackson worked in West of Scotland Regional Plastic Surgery Service, Canniesburn Hospital, Glasgow Royal Infirmary, Glasgow, and Centre for Rheumatic Diseases, Glasgow, and as Honorary Clinical Lecturer, University of Glasgow. He was the Secretary of the British Plastic Surgery Research Committee. All the Plastic Surgery trainees from our subcontinent who were trained in Canniesburn Hospital, Glasgow Royal Infirmary were already familiar with the versatility of Mr. Jackson, and those who did not, came to know him in 1972 from his legendary work on "the groin flap" with Ian McGregor.

In 1979, he crossed the Atlantic and became the Consultant Plastic Surgeon, Mayo Clinic in Rochester, Minnesota, and Head of the Section of Plastic Surgery, a post he held till 1989. He was also the Professor of Plastic Surgery, Mayo Medical School, during this time. In 1989, Mr. Jackson moved to Providence Hospital in Southfield, Michigan, to become the Director, Institute for Craniofacial and Reconstructive Surgery, and Director, Craniofacial Cleft Palate Diagnostic Clinic, which was affiliated to the Providence Hospital. He was also the Chairman of the Institutional Review Board, Department of Physiology, Providence Hospital and Member of their Medical Education Committee.

It was in Providence Hospital that I had the good fortune of working as his fellow. There was an experimental laboratory in which research on craniofacial development and trauma were conducted, and Mr. Jackson invariably found time to attend it despite his busy clinical schedule. His clinical rooms were always busy, and every little detail was attended to by his superefficient office led by Marjorie herself. Not only would Mr. Jackson look into the comprehensive academic, research and clinical training of his fellows but would also arrange for their stay with one of his office staff members. I remember having enjoyed my stay with Eva and she was always very kind and helpful.
Mr. Jackson was a member of many Plastic Surgery and Cleft and Craniofacial Surgery associations, and the Association of Plastic Surgeons of India too honored him with its honorary membership.

An extremely decorated surgeon, he was the Clinician of the Year of American Association of Plastic Surgeons in 1992, Senior Visiting Professor, Plastic Surgery Educational Foundation in 1993, and in 1996, he was awarded the Sir Harold Gillies Gold Medal by British Association of Plastic Surgeons. In 1998, he was decorated with the Royal College of Surgeons of Edinburgh Medal, and in 1999, he received the Honorary Award by the American Association of Plastic Surgeons.

As a journal editor, he was at his best. He was the Editor of European Journal of Plastic Surgery and Plastic Surgery Outlook. He was also part of the editorial board of many journals, including our own Indian Journal of Plastic Surgery and P.R.S ONLINE.

His love for India was legendary as he singlehandedly established Craniofacial Surgery in our country. He first visited us in 1984 during the APSICON in Lucknow where he mesmerized us with his brand of surgery. I too was among the many young surgeons who felt that our training as a Plastic Surgeon was incomplete without getting trained in Craniofacial Surgery, and we all started making a beeline for Providence Hospital in Southfield to be trained by him. I remember proceeding from there to Mr. David's unit in Adelaide, and he was kind enough to write a letter to Mr. David introducing me. I remember being invited to his place for dinners and to weekend outings with his family. He was a very loving and caring person and trainees from India always had a special place in his academy.

During his visits to India, he visited Dr. Adenwalla in Trichur, Kerala, on multiple occasions and the two shared a special bond which lasted their lifetime. He visited IPGMER, Kolkata, twice and encouraged the Kolkata trainees to perform
Address for correspondence Dr. Surajit Bhattacharya, MD, MCh, C-907 Mahanagar, Sector B, Lucknow 226006, Uttar Pradesh, India (e-mail: surajitbh@yahoo.co.in).
DOI https://doi.org/ 10.1055/s-0040-1716475 ISSN 0970-0358.

published online

August 29, 2020
(C)2020 Association of Plastic Surgeons of India
License terms

(1) (1) $\Theta \circledast$ 
microsurgery by presenting a pair of Designs for Vision operating loupes to them. He was the operating faculty in many surgical workshops in New Delhi, Mumbai, Ahmadabad, Chandigarh, Chennai, Bangalore, Pune and many other cities in India, and every Plastic Surgery trainee of our generation knew him and was influenced by his teaching prowess.

Mr. Jackson was a visiting professor to various medical institutions and dental schools all over the world and was greatly respected by his peers and junior colleagues. He had more than 300 publications and more than 7000 citations, and this alone proves the impact he had on Plastic Surgery during his lifetime! If you add to this the number of leaders in Plastic Surgery he created by his expert tutelage, you can imagine the larger than life persona he presented and the adulation he so richly deserved.

If you disregard all this for a moment and only take into account the huge volume of philanthropic activities that he was involved in various developing countries in Latin America, Africa, Eastern Europe and Asia, you will find a person with a large and loving heart who was chosen by God to render help to His most unfortunate children, a task which Mr. Jackson did all his life with all his heart and soul. In his son David, I can see that love in human form. See this video to believe https://www.cbsnews.com/video/ medical-miracle/

Life is finite but glory of a life well lived is infinite and so was the life of Ian T. Jackson. Patients in Lucknow called him "Jai Kishan," an invocation they use for Lord Krishna, and truly here was a man who can be justifiably defined as a "Karmaveer"! In Geeta, Lord Krishna says that a man is born to perform his designated "karma" and only performance of karma is the road to "moksha" or salvation. We are sure our teacher Mr. Jackson's soul will attain eternal "moksha." 